Det er min nat i on of the si ngl e strand or i gi $n$ of Shi gel I a sonnei pl asmi d pKYM

\begin{tabular}{|l|l|}
\hline 著者 & $\begin{array}{l}\text { KODAl RA Ken- I chi , OK Nasaya, TAKETO Aki r a, } \\
\text { YASUKAMA H r oo, MASAMUNE Yuki to }\end{array}$ \\
\hline $\begin{array}{l}\text { j our nal or } \\
\text { publ i cat } \mathrm{i} \text { on t i t l e }\end{array}$ & Bi ochi mi ca et Bi ophysi ca Act a \\
\hline vol ume & 1260 \\
\hline number & 2 \\
\hline page r ange & 183 190 \\
\hline year & $1995-01$ \\
\hline URL & ht t p: //hdl . handl e. net /10098/1619 \\
\hline
\end{tabular}




\title{
Determination of the single strand origin of Shigella sonnei plasmid pKYM
}

\author{
Ken-Ichi Kodaira $^{\text {a }}$, Masaya Oki ${ }^{a}$, Akira Taketo ${ }^{b}$, Hiroo Yasukawa ${ }^{c}$, Yukito Masamune ${ }^{c}$ \\ a Molecular Biology Group, Chemical and Biochemical Engineering, Faculty of Engineering, Toyama University, 3190, Gofuku, Toyama, \\ Toyama 930, Japan \\ ' Department of Biochemistry, Fukui Medical School, Matsuoka, Fukui, Fukui 910-11, Japan \\ ' Department of Microbiology, Faculty of Pharmaceutical Sciences, Kanazawa University, Kanazawa, Ishikawa 920 , Japan
}

\begin{abstract}
The Shigella sonnei plasmid pKYM replicates by a rolling-circle mechanism in Escherichia coli. A 571 nucleotides HincII restriction fragment of the pKYM DNA harbors two potential hairpin loops (I and II). We cloned the fragment into a -ori defective M13 vector phage, M13 $\Delta$ lac183. The chimera phage, MDKY5, showed a larger plaque size, and increased phage yield and rate of progeny replicative form DNA (RF) synthesis. Rifampicin reduced rate of conversion of the single- to double-stranded RF DNA. In addition, we introduced nucleotide deletions within the cloned pKYM DNA, by Bal31 nuclease digestion. Each of the deletion mutants thus constructed was lacking in a sequence containing the hairpin loops and formed smaller plaques. The in vivo analyses revealed that a 136 nucleotides sequence containing the two hairpins I and II is the pKYM minus origin for complementary strand synthesis (single strand origin, referred to as $\mathrm{SSO}$ ) and harbors a recognition site(s) by host E. coli RNA polymerase, for primer RNA synthesis. Moreover, we found a 24 nt sequence, upstream of the SSO domain having $83 \%$ homology to the recombination site $A\left(\mathrm{RS}_{\mathrm{A}}\right)$ which functions in plasmid sitespecific recombination and/or transfer.
\end{abstract}

Keywords: Single-stranded DNA plasmid; Origin mutant; Deletion; Complementary strand; DNA sequence

\section{Introduction}

A small cryptic plasmid pKYM with a 2083 nucleotide (nt) double-stranded circular DNA was originally isolated from Gram-negative bacterium Shigella sonnei [1,2]. pKYM can grow normally in Escherichia coli [1] and belongs to a single-stranded (SS) DNA plasmid family that replicates by a rolling-circle mechanism via SS DNA intermediates $[3,4]$.

As in various Gram-positive bacterial SS DNA plasmids such as pUB110 from Staphylococcus (St.) aureus (see for a review [5]), the pKYM replicon has three key elements for its rolling-circle replication [3,4]: (i) an origin for plus strand synthesis (+ori), (ii) a replication protein (rep, 321 amino acids long) that nicks a unique site within the +ori domain (located upstream of the rep gene), attaches to the $5^{\prime}$ nick terminus via a phosphotyrosine linkage (Tyr-237), displaces the plus strand, and renicks and ligates at the newly generated +ori after one round replication, and (iii) an origin(s) for minus strand replication (SSO).

Contrary to the +ori / rep system, pKYM has no SSO sequences homologous to those of any other SS DNA plasmids [6]. More recently, we [7] have identified a possible pKYM SSO region within an approx. $400 \mathrm{nu}$ cleotide (nt) sequence located upstream of the +ori; the sequence has two potential secondary structure hairpin loops I and II showing remarkable similarity to -ori sequences of $E$. coli filamentous SS DNA phages fd, f1 and M13 [8-10].

In order to elucidate molecular and evolutional properties of SSO structure, we determined an essential $136 \mathrm{nt}$ sequence of pKYM SSO by a deletion mapping method using Bal31 nuclease. Moreover, we found a 24 nt sequence located upstream of the PKYM SSO, which shows $83.3 \%$ homology with the conserved plasmid recombination site $\left(\mathrm{RS}_{\mathrm{A}}\right)$. These results are discussed in relation to the role of secondary structures in the SSO region and to the plasmid transfer. 


\section{Materials and methods}

\subsection{Bacteria, plasmids and phages}

E. coli strains JM109 [11] and XL1-blue [12], plasmid pKYM, and bacteriophage M13 $\Delta$ lac183 were from our laboratory stock $[7,13]$.

\subsection{Enzymes and biochemicals}

Restriction enzymes, phage T4 DNA ligase, E. coli DNA polymerase I (Klenow fragment), Bal31 nuclease, and reagents used for dideoxy sequencing were purchased from CalBiochem (USA), Takara Shuzo (Kyoto) and Nippon Gene (Toyama). Buffers for the enzymes were as recommended by the manufacturer. $\left[\alpha-{ }^{35} \mathrm{~S}\right] \mathrm{dCTP}$ was from NEN. All other materials were prepared as described previously $[14,15]$.

\subsection{Construction of mutant}

Double-stranded pKYM DNA was digested with restriction endonuclease HinclI. A 571 nt Hincll fragment (see below) was cloned into a unique SmaI site of the M13 $\Delta$ lac183 vector. Hybrid phages thus obtained were referred to as MDKY5 and MDKY3: the former has the two putative hairpins on the viral strand of M13 $\Delta$ lac183 (correct direction), whereas the latter has the hairpins on the M13 $\Delta$ lac183 complementary strand (reversed direction). For deletion analysis, two derivatives MDKY55 and MDKY53 were constructed from MDKY5 (in details, see below). Using these two strains, we introduced deletions into the pKYM SSO by Bal31 nuclease digestion, as described previously [16].

\subsection{Analysis of phage growth}

E. coli JM109 cells were grown at $37^{\circ} \mathrm{C}$ with shaking in 2YT medium [15]. When the $A_{660}$ of the culture had reached 0.15 , phage (input multiplicity, 0.1 ) was added. At intervals, aliquots were removed, treated with chloroform and then free phage was titrated [17].

\subsection{Analysis of DNA synthesis}

E. coli JM109 cells were grown at $37^{\circ} \mathrm{C}$ with shaking in 2YT medium. When the $A_{660}$ of the culture had reached 0.3 , phage (input multiplicity, 10) was added. At intervals, phage DNA was extracted by alkaline method [18] and analyzed with $1 \%$ agarose gel electrophoresis.

For Southern blotting, $E$. coli JM109 cells were grown at $37^{\circ} \mathrm{C}$ with shaking in $2 \mathrm{YT}$ medium. When the $A_{660}$ of the culture had reached 0.46 , rifampicin $(100 \mu \mathrm{g} / \mathrm{ml})$ was added. After $10 \mathrm{~min}$ incubation, phage was added (input multiplicity, 10) and the infected culture was incubated for $30 \mathrm{~min}$. The intracellular viral DNA was extracted by alkaline method and electrophoresed on $1 \%$ agarose gel, followed by transfer to a nylon membrane (Hybond-N; Amersham). ${ }^{32} \mathrm{P}$-labeled probes were prepared by nick translation, using the pKYM Hincll fragment. All other procedures for Southern blot hybridization were the same as described previously $[2,19]$.

\subsection{DNA sequencing}

The nucleotide sequence of the SSO region was determined by the chain termination method [20] using universal vector primers. All other procedures were performed as described previously [21].

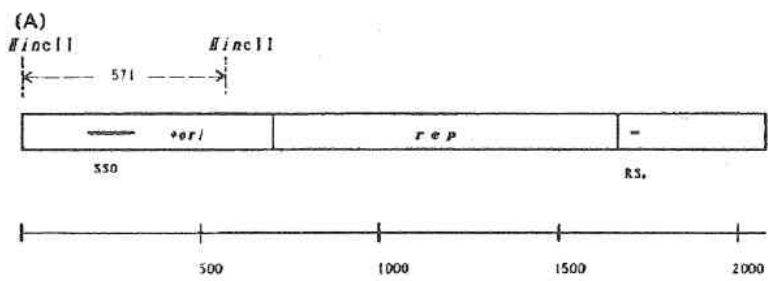

( B )

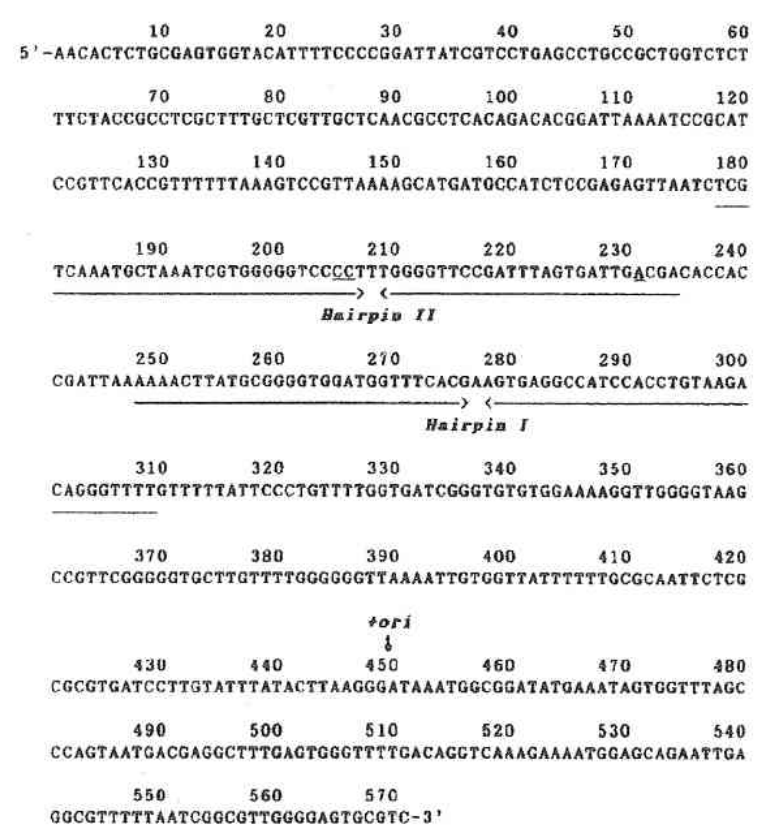

Fig. 1. Genome structure of the pKYM DNA. (A) Gene organization of pKYM is illustrated. SSO; the minus origin for complementary strand synthesis (this study), + ori; the plus origin for leading strand replication [3], rep; the replication protein [2], $\mathrm{RS}_{\mathrm{A}}$; the plasmid recombination site (see Fig. 3). The Hincll fragment (571 nucleotides) used in this study is highlighted by arrows. (B) DNA sequence of the 571 nucleotides Hinc II fragment is presented. The two potential secondary structure hairpin loops $I$ and II are shown by arrows. Three nucleotides revised in this study (see text) are underlined. +ori, the plus origin for viral strand synthesis; $\downarrow$, the nicking site for rep protein. 


\section{Results}

\subsection{General properties of $p K Y M S S O$}

Fig. 1A shows the pKYM genome structure $[2,3]$. As described above, pKYM SSO was localized upstream of the +ori domain. In this study, we resequenced pKYM DNA and found three differences in the SSO region with the previously published sequence [2]. The new sequence of $571 \mathrm{nt} H$ Hincll fragment containing the SSO is presented in Fig. 1B: an extra dinucleotide CC at nt position 205-206 and an extra $\mathrm{A}$ at position 231. Consequently, the complete pKYM DNA is $2086 \mathrm{nt}$ long.

The Hincll fragment contains two possible hairpin loops I and II, which are positioned from nt 248 to 309 and from nt 178 to 234, respectively (Figs. $1 \mathrm{~B}$ and 2). As indicated by us [7] as well as Seery et al. [22], these secondary structures show extensive sequence homology (74.0\%, Fig. 2A), over 140 nt from nt 178 to 317 , with those of - ori regions of $E$. coli filamentous phages fd [8], f1 [9], and M13 [10]. In Fig. 2B, the pKYM hairpin loops are compared with those of fd [8].

In addition, like fd, $\mathrm{pKYM}$ has a nucleotide $\mathrm{T}$ (located at nt 315, see Figs. $1 \mathrm{~B}$ and 2) at 6 nt upstream of the hairpin I; the fd $\mathrm{T}$ has been considered as a starting point for primer RNA synthesis ('primer point') by host $E$. coli RNA polymerase [8].

On the other hand, we found that a $24 \mathrm{nt}$ sequence 5'-AAATAAGaGTATTGGtTTATttTT-3' located from nt 1698 to 1723 (see Fig. 1A) has $83.3 \%$ sequence homology with the conserved 'core' sequence of plasmid recombination site $\left(\mathrm{RS}_{\mathrm{A}}\right)$ [23]. The $\mathrm{RS}_{\mathrm{A}}$ site has been detected in various Gram-positive bacterial plasmids: St. aureus plasmids (pE194, pT181, and pUB110) [24], Streptococcus (Sc.) agalactiae plasmid pMV158 [25], and Lactobacillus (Lb.) plasmids including pLAB 1000 from $L b$. hilgardii [25]), pLB4 from Lb. plantarum [26], and $\mathrm{pNMO}$ from $L b$. strain N1f (Kodaira et al., unpublished data). In Fig. 3, the $\mathrm{pKYM} \mathrm{RS}_{\mathrm{A}}$ sequence is compared with those of Gram-positive bacterial plasmids. Recently, Selinger et al. [27] pointed out that the $\mathrm{RS}_{\mathrm{A}}$ domain might be used as an origin for plasmid transfer between bacteria, besides as a recombination site for plasmid cointegrate and/or resolution (see below).

\subsection{Cloning of $\mathrm{PKYM} S S O$}

To determine pKYM SSO domain, we cloned the 571 nt Hincll fragment (Fig. 1) into a unique SmaI site of minus origin defective phage vector, M13 $\Delta$ lac183. Hybrid phages thus obtained were referred to as MDKY5 and MDKY3 which harbor the two secondary hairpins I and II in correct and reversed directions, respectively, as described in Materials and methods. The MDKY5 strain (equivalent to the M13 $\Delta$ lac183-4 as in [7]) formed plaques larger than those of the MDKY3 strain, as well as the parental M13 $\Delta$ lac183 (data not shown), indicating that the HincII fragment has a SSO activity.

\subsection{Growth properties of MDKY5 strain}

In order to confirm the SSO activity, we performed phage growth experiments. When E. coli JM109 cells were infected with the MDKY5 strain at $37^{\circ} \mathrm{C}$, the phage

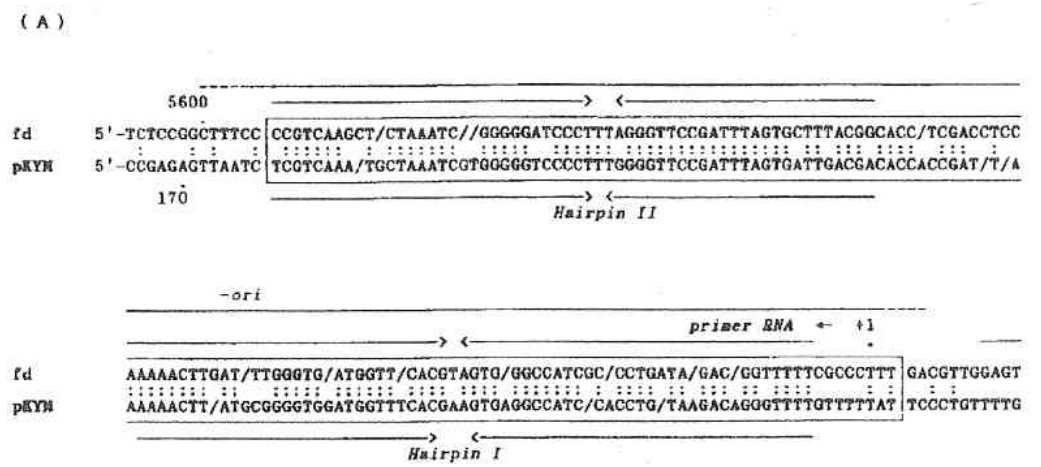

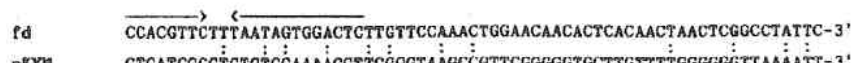

Fig. 2. Structure of the pKYM SSO. (A) DNA sequence of the pKYM SSO (this study) is compared with the -ori of E. coli filamentous phage fd [8]. Identical nucleotides between fd and pKYM are indicated by (:). Slashes represent gaps inserted to align nucleotides for maximal homology. The two putative secondary hairpin loops I and II are indicated with arrows. The fd -ori domain is boxed by dotted line; its sequences recognized by RNA polymerase are shown by horizontal line [8]. +1, a putative starting point for fd primer RNA synthesis [8]. (B) Secondary structures of pKYM SSO and fd - ori domains are compared. Sequences of $\mathrm{pKYM}$ and fd are from this study and [8], respectively. Nucleotides of fd identical to those of pKYM are presented by capital letters. 
( B )
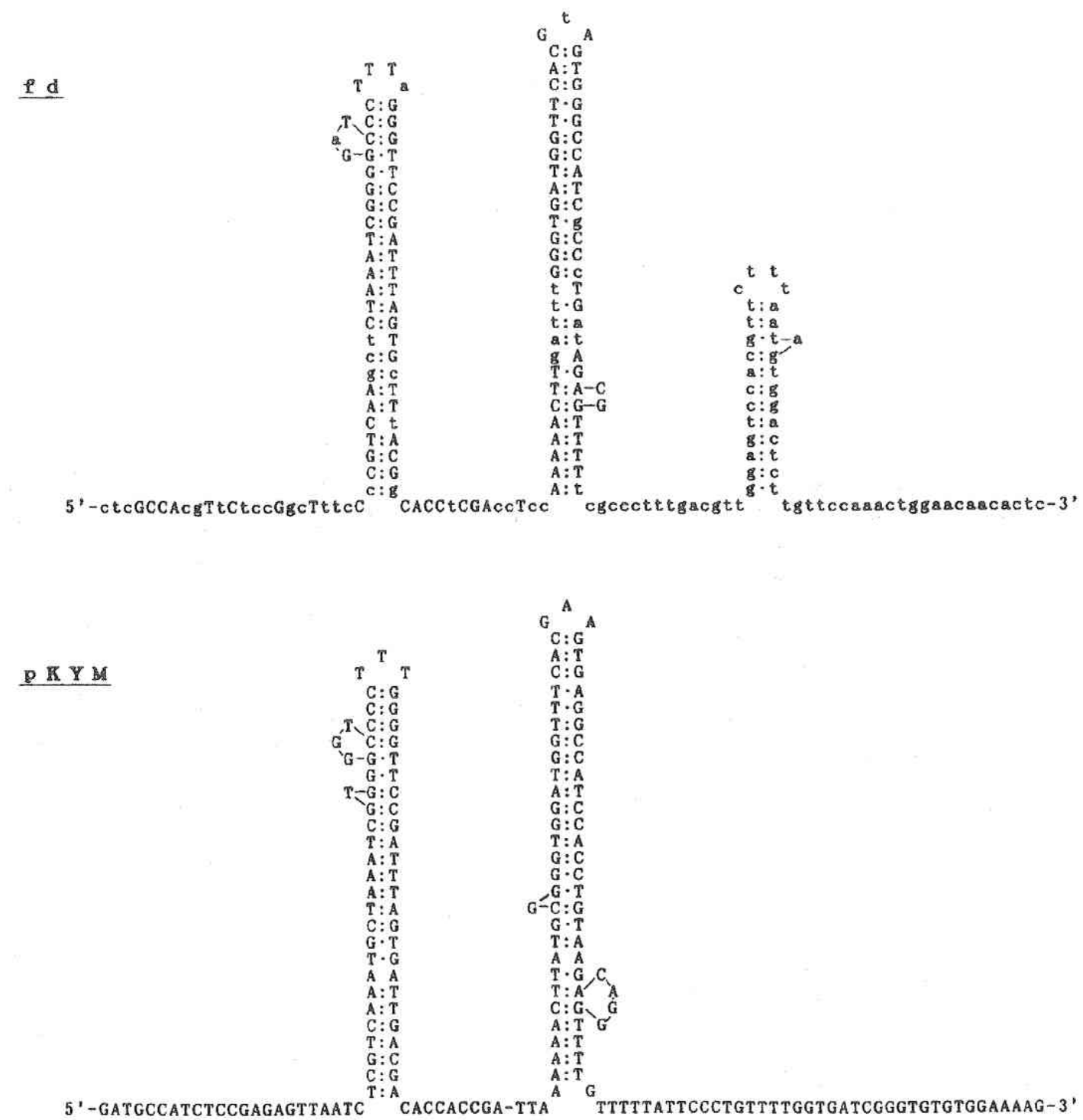

Fig. 2 (continued).

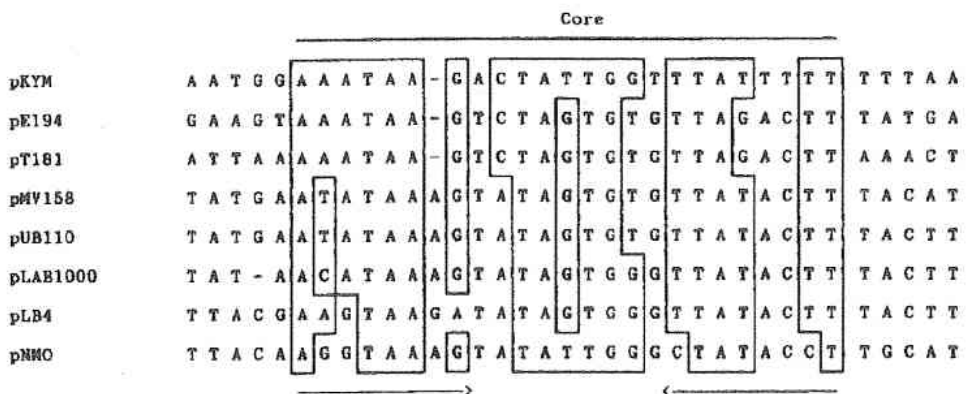

Fig. 3. Similarities among recombination sites of pKYM and other Gram-positive bacterial plasmids. Sequences of pKYM, pE194, pT181, pMV15 and, pUB110, pLAB1000, pLB4, and pNMO are from $[2,30,24,31,24,26]$ and Kodaira et al. (unpublished data), respectively. Core sequence is represented by horizontal line. Identical nucleotides are boxed. Imperfect inverted repeats are indicated by arrows. 


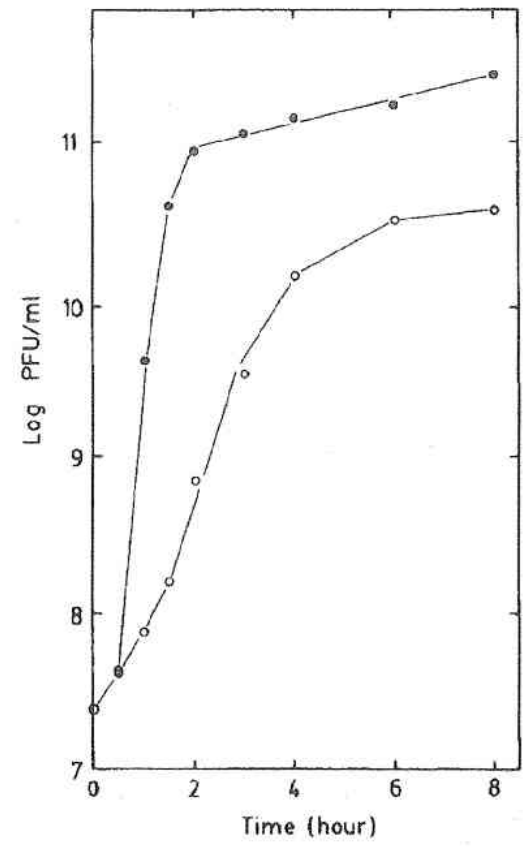

Fig. 4. Analysis of phage growth. Cells of E. coli JM109 $\left(3.0 \cdot 10^{8} / \mathrm{ml}\right)$ grown at $37^{\circ} \mathrm{C}$ were infected with phage (input multiplicity, 0.1 ) in $2 \mathrm{YT}^{\mathrm{T}}$ medium [13]. At intervals, aliquots were removed, treated with chloroform and then free phage was titrated. O, M13 $\Delta$ lac183; ㄱ, MDKY5.

yield was about one order higher at $8 \mathrm{~h}$ after infection than that of the parental M13 $\Delta$ lac183 (Fig. 4) as well as the MDKY3 strain (data not shown).

The SSO region of SS DNA plasmid is utilized in the conversion of newly synthesized closed circular plus strand into the parental replicative form (RF) DNA [3,5]. To study effects of the pKYM SSO on the hybrid viral DNA replication in vivo, rate of the RF synthesis was measured in $E$. coli JM109. The cells were infected with the MDKY5 strain and the intracellular viral DNA was subjected to agarose gel electrophoresis analysis. Fig. 5A shows RF synthesis of the MDKY5 strain comparing with that of the parental M13 $\Delta$ lac183. Amount of MDKX5 RF DNA accumulated after infection was increased in parallel with increase in phage yield (see Fig. 4).

In comparison with fd - ori [8], we examined dependency of the pKYM SSO on $E$. coli RNA polymerase. $E$. coli JM109 cells treated with rifampicin $(100 \mu \mathrm{g} / \mathrm{ml})$, an inhibitor of RNA polymerase, were infected with MDKY5 and then the intracelluar viral DNA was analyzed using Southern blot hybridization, as described in Materials and methods. As shown in Fig. 5B (lane o), MDKY5 SS DNA was accumulated after rifampicin treatment and its RF formation was strongly inhibited, demonstrating that SS DNA molecules were intermediates for its rolling-circle replication; linear-like molecules migrated slower than closed-circular DNA (RFI) may be derived from a cryptic origin(s) in M13 $\Delta$ lac183 DNA which is probably independent of RNA polymerase $[14,16]$. In the presence of chloramphenicol (30 and $150 \mu \mathrm{g} / \mathrm{ml}$ ), no such SS DNA intermediates were detected (Fig. 5B, lanes $m$ and $n$, respectively).

These observations suggest that the $571 \mathrm{nt}$ sequence contains a unique pKYM SSO domain and harbors a recognition site(s) of $E$. coli RNA polymerase which is involved in primer RNA synthesis for complementary strand replication. In the pKYM hairpins, we found putative transcription initiation signals, at -35 and -10 regions (see below).

\section{4. pKYM SSO mutants}

To elucidate to what extent the secondary structure of the hairpin loops I and II is essential, we introduced

A

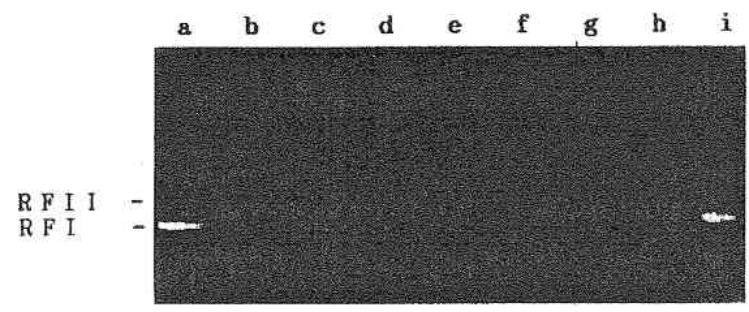

B

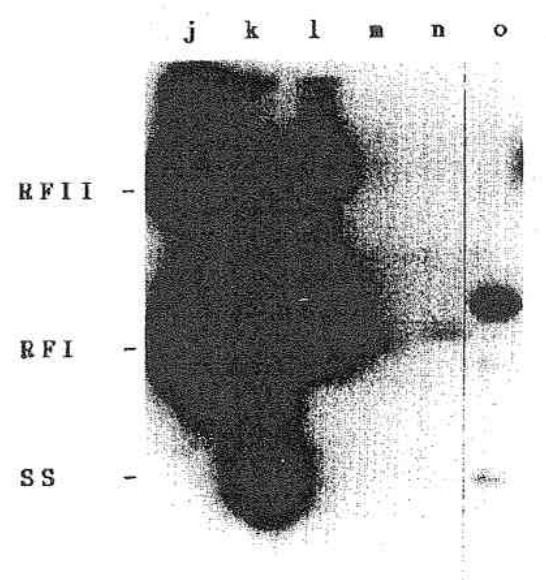

Fig. 5. Rate of synthesis of MDKY5 RF DNA. (A) Cells of E. coli JM109 $\left(5.0 \cdot 10^{8} / \mathrm{ml}\right)$ grown at $37^{\circ} \mathrm{C}$ were infected with phage (input multiplicity, 10) at $37^{\circ} \mathrm{C}$ in $2 \mathrm{YT}$ medium [13]. At $20,40,60$, and $90 \mathrm{~min}$ postinfection, the intracellular viral DNA was extracted and subjected to $1 \%$ agarose gel electrophoresis. a, control MDKY5 RF DNA; b, c, d, and e, M13 $\Delta$ lac 183 at $20,40,60$, and 90 min, respectively; $\mathrm{f}, \mathrm{g}, \mathrm{h}$, and $\mathrm{i}$. MDKY5 at 20, 40,60, and $90 \mathrm{~min}$, respectively. (B) Cells of $E$. coli JM109 $\left(5.0 \cdot 10^{8} / \mathrm{ml}\right)$ grown at $37^{\circ} \mathrm{C}$ in $2 \mathrm{YT}$ medium [13] were treated with rifampicin or chloramphenicol for $10 \mathrm{~min}$ and then phage was added (input multiplicity, 10). After $30 \mathrm{~min}$ incubation, the intracellular viral DNA was extracted and subjected to $1 \%$ agarose gel electrophoresis. The viral DNA was detected with Southern blot hybridization as described in Materials and methods. j, MDKY5 RF DNA; $k$, MDKY5 SS DNA; 1 , no inhibitor, $\mathrm{m}$, chloramphenicol $(30 \mu \mathrm{g} / \mathrm{ml}) ; \mathrm{n}$, chloramphenicol $(150$ $\mu \mathrm{g} / \mathrm{ml}) ; o$, rifampicin $(100 \mu \mathrm{g} / \mathrm{ml})$. 
nucleotide deletions within the PKYM SSO by the method of $\mathrm{Bal} 31$ nuclease digestion [16].

For deletion mapping, we constructed two derivatives of the MDKY5 strain, as probes (for details, see Fig. 6). One derivative, MDKY53, has $420 \mathrm{nt}$ sequence spanning from HincII (located at nt 1) to AccII (at nt 421) sites, and the other derivative, MDKY55, contains $284 \mathrm{nt}$ sequence from DraI (at nt 137) to Acc II (at nt 421) sites (both of the derivatives have restriction enzyme sites for introduction of deletion, at their flanking regions). The two strains formed plaques as large as those of the parental MDKY5 (data not shown).

Deletion mutants thus obtained were referred to as delMDKY53 or delMDKY55. To determine the mutation sites precisely, the mutants were subjected to sequence analysis by the chain termination method [20] using universal vector primers. Each mutant had an expected mutation within the secondary structures. In Fig. 7, their mutation sites are summarized and compared with the $\mathrm{fd}$-ori sequence.

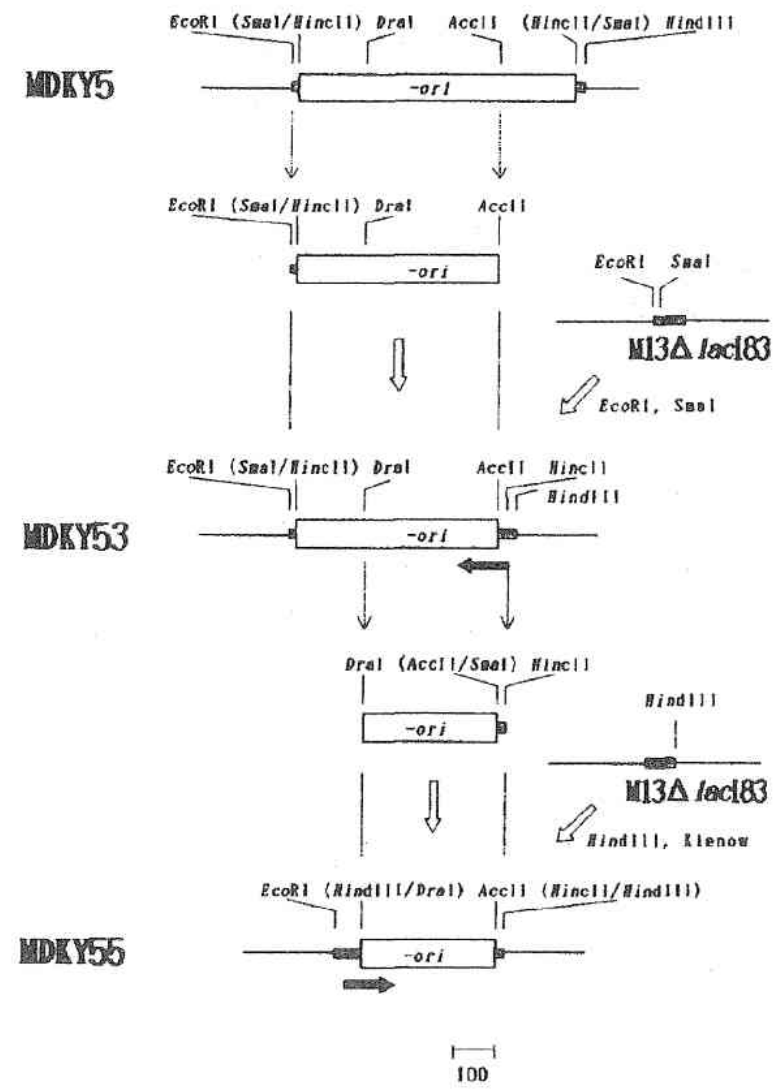

Fig. 6. Construction of MDKY53 and MDKY55 derivatives. MDKY5 RF DNA (see text) was cut by restriction enzymes EcoRI and AccII and the EcoRI/AccII fragment was recloned into M13 4 lac183 using is EcoRI/SmaI sites. The resulted derivative was referred to as MDKY53. A DraI/HincIl fragment of MDKY53 was recloned into M13 $\triangle$ lac183 using its endfilled HindIII site and a MDKY55 derivative was obtained. Regions containing multi-cloning site are indicated by dashed box.
Mutants missing a sequence within the two hairpins formed smaller plaques like M13 $\Delta$ lac183: (1) two mutants delMDKY55-246 and -207 had 16 and 26 nt deletions, respectively, within the $5^{\prime}$ stem of hairpin II, (2) delMDKY55-227 lost the two hairpins entirely, but still had the primer point (see above), whereas (3) delMDKY53-129 and -123 mutants missed almost all of the SSO region containing the $3^{\prime}$ stem of hairpin II, a region between the hairpins I and II ('loop space'), the hairpin I, and the primer point, (4) delMDKY53-139 was lacking in the $3^{\prime}$ region of loop space and the hairpin I, besides the primer point, (5) delMDKY53-125 and -147 mutants missed almost all of the hairpin I and the primer point.

Contrary to these mutants yielding smaller plaques, delMDKY53-163 formed plaques as large as those of the parental MDKY53; the mutant lost the primer point and 3 nt $\left(5^{\prime}-\right.$ TTT $\left.-3^{\prime}\right)$ at the base in the $3^{\prime}$ stem of hairpin I. Other two mutants delMDKY53-2 and -9, lacking in the primer point but not the secondary structures, also produced larger plaques. In the case of $5^{\prime}$ mutant, del MDYK55-197 formed larger plaques; it still had the entire secondary structures and the $5^{\prime}$ flanking 7 nt $5^{\prime}$-GTTAATC- $3^{\prime}$.

These sequencing results revealed that the pKYM SSO consists of 136 nt located from nt 171 to 306 (see Figs. 1 and 7) which comprise the two secondary hairpins I and II.

\section{Discussion}

An abundance of plasmid species replicating by a rolling-circle mechanism have been found in various Gram-positive and-negative bacteria. Contrary to their +ori/Rep systems, structure and function of the SSO domains are remarkably divergent; they are different in DNA sequence, albeit rich in distinct secondary structures. This is mainly due to different dependency of the SSO domains on host replication proteins, including DNA primase, RNA polymerase, and so on. They can be divided into several groups, such as palA, BA3 (or palU), BAA1, $\mathrm{fd}, \phi \times 174, \mathrm{G} 4$ and other types [24,25], but their evolutionary relationship is at present unclear.

In this study, the SSO domain of a small cryptic Shigella sonnei plasmid, pKYM (2086 nt DNA), was determined within a $136 \mathrm{nt}$ sequence which contains the two secondary structure hairpin loops I and II (Fig. 2B) with $75.4 \%$ homology with the - ori of $E$. coli filamentous phage fd (Fig. 2A). The pKYM SSO sufficiently functioned in a -ori defective phage vector M13 $\Delta$ lac183 (Figs. 4 and 5A) and its activity was inhibited by rifampicin, an inhibitor against to $E$. coli RNA polymerase (Fig. 5B).

These in vivo analyses demonstrated that the $136 \mathrm{nt}$ secondary structures (the hairpin I, the loop space, and the hairpin II) are essential for recognition by $E$. coli RNA polymerase, which synthesizes a primer RNA for comple- 

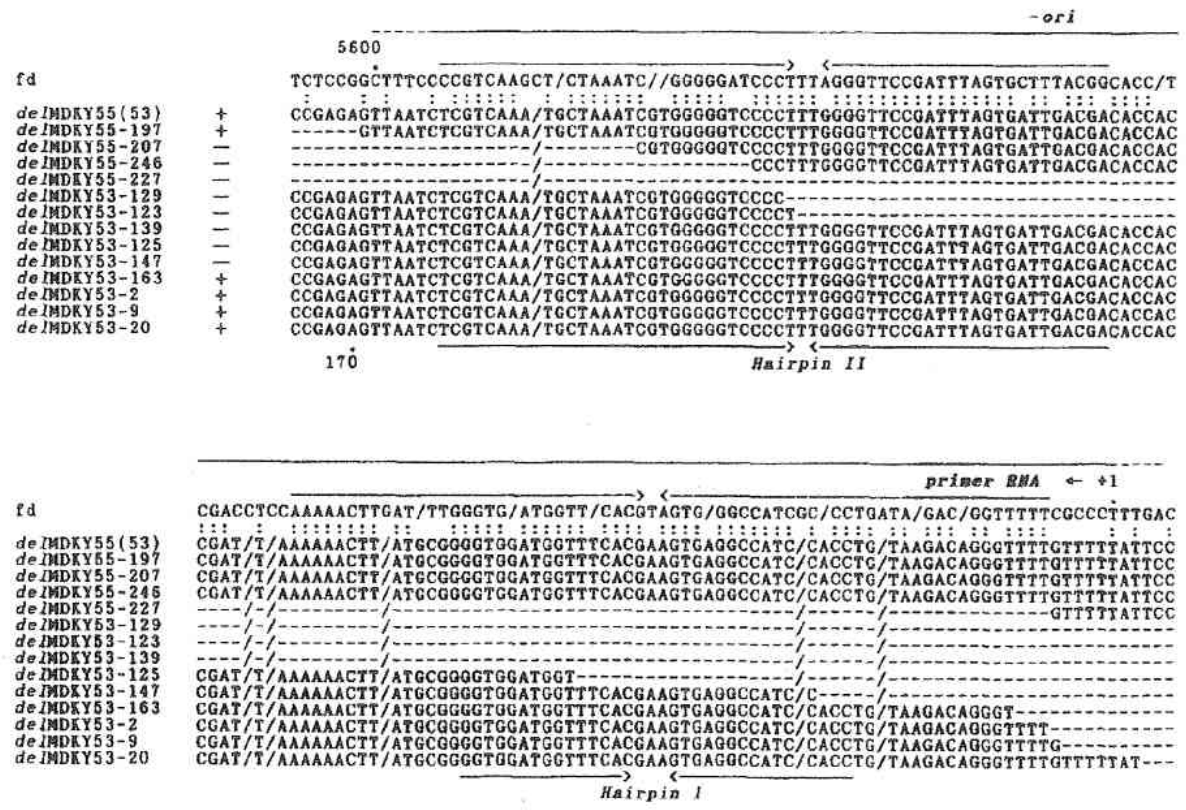

Fig. 7. Nucleotide sequences of the SSO mutants. Identical nucleotides between fd and PKYM are indicated by (:). Slashes represent gaps inserted to align nucleotides for homology. Putative secondary hairpin loops are shown with arrows. Deletion mutants of pKYM are described in the text. Deleted nucleotides are indicated with dashes. +, large plaques; -, small plaques. Other symbols are shown in Fig. 2.

mentary strand replication. It is interesting that the pKYM hairpins have possible transcription initiation signals; a sequence $5^{\prime}$-TTGACG-3' (positioned from nt 228 to 233 , see Fig. 1) for the -35 region is located on the $3^{\prime}$ stem of hairpin II, whereas a sequence $5^{\prime}$-TATGcgG-3' (from nt 254 to 259 ) for the -10 region is positioned on the $5^{\prime}$ stem of hairpin I. The two putative signals separated by definite $20 \mathrm{nt}$ are shown in Fig. 8, in comparison with well characterized promoters of $E$. coli phages fd [28] and $\phi X 174$ [29]. Upon recognition by $E$. coli RNA polymerase of these sequences for primer RNA synthesis, nucleotide A located at nt 287 and/or dinucleotide GG at position 283-284 are most probable initiation points. This observation coincides well with the fact that the three deletion mutants delMDKY53-163, -9 , and -2 are lacking in the nucleotide $\mathrm{T}$ at nt 315 (see Fig. 7).

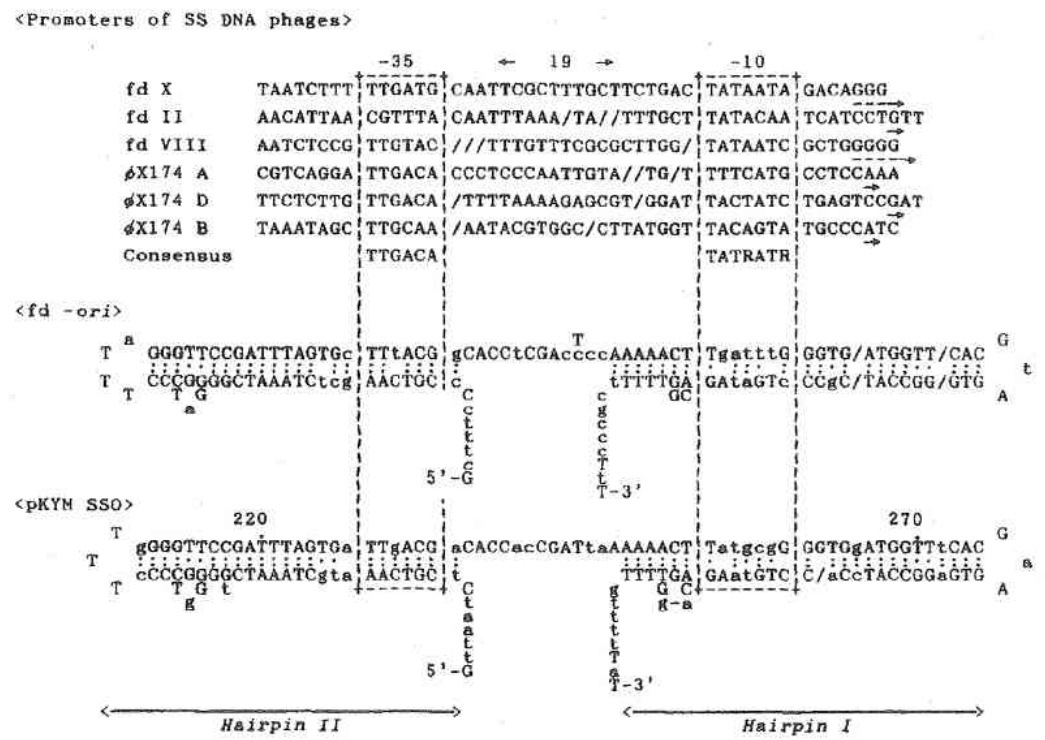

Fig. 8. Transcription initiation signals of pKYM SSO. Promoters of $\mathrm{fd}$ and $\phi \mathrm{X} 174$ are from $[28,29]$, respectively (mRNA starting points are represented by small arrows and slashes represent gaps inserted to align nucleotides for maximal homology). The sequences of fd - ori and pKYM SSO are from [8] and this study, respectively. The two putative secondary hairpins I and II are arrowed. 
Previously, Yasukawa et al. [3] indicated that genetic organization of the pKYM + ori/rep system resembles that of the pUB110 family, such as pC194 (from St. aureus) and suggested that pKYM as a plasmid of the pUB110 family was transferred accidentally to Gram-negative bacterium.

In pKYM DNA, we found a $\mathrm{RS}_{\mathrm{A}}$-like sequence with $83 \%$ homology with the conserved $\mathrm{RS}_{\mathrm{A}}$ domain (core sequence) found in various Gram-positive bacterial plasmids (see above). The core sequence plays an important role in site-specific recombination for plasmid cointegration and/or resolution as a unique target site of plasmidencoding recA-independent recombinase, Pre (plasmid recombination) [24]. In Staphylococcus plasmids such as pT181 and pE194, pre-mediated recombination occurs between inter (as well as intra) molecular $\mathrm{RS}_{\mathrm{A}}$ sites [11]. Recently, Selinger et al. [27] indicated that nonconjugative plasmid pUB110 (from St. aureus) or pBC1 (from Bacillus cereu) possessing Pre/RS $\mathrm{R}_{\mathrm{A}}$ system can be transferred to other strain through its $\mathrm{RS}_{\mathrm{A}}$ site, with the help of a conjugative plasmid. Thus, the putative transfer of $\mathrm{pKYM}$ to a Gram-negative bacterium [3] might have been mediated by its $\mathrm{RS}_{\mathrm{A}}$ sequence and have acquired a SSO domain which can be recognized by Gram-negative bacterial RNA polymerase, as in $E$. coli filamentous phages such as $\mathrm{fd}$, but not in spherical phages $\mathrm{G} 4$ and $\phi \times 174$ requiring bacterial primase $[14,15]$.

\section{References}

[1] Sugiura, S., Nakatani, S., Mizukami, Y., Hase, T., Hirokawa, H. and Masamune, Y. (1984) J. Biochem. 96, 1193-1204.

[2] Hirose, T., Sugiura, S., Shibata, H., Hase, T., Nakanishi, Y. and Masamune, Y. (1988) Yakugaku Zasshi 108, 886-893.

[3] Yasukawa, H., Hase, T., Sakai, A. and Masamune, Y. (1991) Proc. Natl. Acad. Sci. USA 88, 10282-10286.

[4] Hase, T., Watanabe, M., Yasukawa, H. Masamune, Y. (1991) J. Gen. Appl. Microbiol, 38, 353-361.

[5] del Solar, G., Moscoso, M. and Espinosa, M. (1993) Mol. Microbiol. 8, $789-796$.

[6] van der Lelie, D., Bron, S., Venema, G. and Oskam, L. (1989) Nucleic Acids Res. 17, 7283-7294.

[7] Yasukawa, H., Hase, T. and Masamune, Y. (1993) J. Gen. Appl. Microbiol. 39, 237-245.
[8] Schaller, H., Beck, E. and Takanami, M. (1978) In the SingleStranded DNA Phages (Denhardt, D.T., Dressler, D. and Ray, D.S., eds.), pp. 139-163, Cold Spring Harbor Laboratory, Cold Spring Harbor.

[9] Hill, D.F. and Petersen, G.B. (1982) J. Virol. 44, 32-46.

[10] Van Wezenbeek, P.M.G.F., Hulsebos, T.J.M. and Schoenmarkers, G.G. (1980) Gene 11, 129-148.

[11] Yanish-Perron, C., Vieira, J. and Messing, J. (1983) Gene 33, $103-119$.

[12] Bullock, W.O., Fernandez, J.M. and Short, J.M. (1987) Biotechnology $5,376-378$.

[13] Kodaira, K.-1., Nakano, K. and Taketo, A. (1989) Biochim. Biophys. Acta 1007, 359-362.

[14] Kodaira, K.-I., Nakano, K. and Taketo, A. (1990) Mol. Gen. Genet. $220,240-244$.

[15] Kodaira. K.-I., Nakano, K., Okada, S. and Taketo, A. (1992) Biochim. Biophys. Acta 1130, 277-288.

[16] Nakano, K., Kodaira, K.-I. and Taketo, A. (1990) Biochim. Biophys. Acta $1048,43-49$.

[17] Kodaira, K.-I. and Taketo, A. (1984) Mol. Gen. Genet. 195, 541-543.

[18] Sambrook, J., Fritsch, E.F. and Maniatis, T. (1989) Molecular cloning: a Laboratory manual, Cold Spring Harbor Laboratory Press, Cold Spring Harbor.

[19] Hosono, R., Hekimi, S., Kamiya, Y., Sassa, T., Murakami, S., Nishiwaki, K., Miwa, J., Taketo, A. and Kodaira, K.-I. (1992) J. Neurochem. 58, 1517-1525.

[20] Sanger, F., Nicklen, S. and Coulson, A.R. (1977) Proc. Natl. Acad. Sci. USA 74, 5463-5467.

[21] Kodaira. K.-1., Nakano, K. and Taketo, A. (1985) Biochim. Biophys. Acta $825,255-260$.

[22] Seery, L.T., Nolan, N.C., Sharp, P.M. and Devine, K.M. (1993) Plasmid 30, $185-196$.

[23] Gennaro, M.L., Kornblum, J. and Novick, R.P. (1987) J. Bacteriol. $169,2601-2610$.

[24] Novic, R.P. (1989) Annu. Rev. Microviol. 43, 537-565.

[25] Josson, K., Soetaert, P., Michiels, F., Joos, H. and Mahillon, J. (1990) J. Bacteriol. 172, 3089-3099.

[26] Bates, E.E.M. and Gilbert, H.J. (1989) Gene 85, 253-258.

[27] Selinger, L.B., McGregor, N.F., Khachatourians, G.G. and Hynes, M.F. (1990) J. Bacteriol. 172, 3290-3297.

[28] Konings, R.N.H. and Schoenmarkers, J.G.G. (1978) In the SingleStranded DNA Phages (Denhardt, D.T., Dressler, D. and Ray, D.S., eds.), pp. 507-530, Cold Spring Harbor Laboratory, Cold Spring Harbor.

[29] Fujimura, F.K. and Hayashi, M. (1978) In the Single-Stranded DNA Phages (Denhardt, D.T., Dressler, D. and Ray, D.S., eds.), pp. 485-505, Cold Spring Harbor Laboratory, Cold Spring Harbor.

[30] Horinouchi, S. and Weisblum, B. (1982) J. Bacteriol. 150, 804-814.

[31] McKenzie, T., Hoshino, T., Tanaka, T and Sueoka, N. (1986) Plasmid 15, 93-103. 